\title{
PERANCANGAN DAN IMPLEMENTASI PROTOTIPE SISTEM KEAMANAN RUMAH MELALUI KOMBINASI KUNCI PINTU DAN PESAN SINGKAT BERBASIS MIKROKONTROLER
}

\author{
Christovan Hutahaean', Ekki Kurniawan ${ }^{2}$, Porman Pangaribuan ${ }^{3}$ \\ 1,2,3 Prodi Teknik Elektro, Fakultas Teknik Elektro, Universitas Telkom \\ chrisstovan@student.telkomuniversity.ac.id ${ }^{1}$, ekkikurniawan@telkomuniversity.ac.id², \\ porman@telkomuniversity.ac.id ${ }^{3}$
}

\begin{abstract}
Abstrak
Home security adalah kebutuhan wajib setiap pemilik rumah dalam menghindari dan meminimalisir tindakan kriminalitas berupa perampokan atau pembobolan rumah. Salah satu contoh sistem tradisional yang masih banyak digunakan adalah alarm rumah. Tetapi seiring dengan perkembangan teknologi saat ini sistem keamanan rumah semakin banyak jenisnya. Sistem keamanan rumah yang diterapkan melalui kombinasi pengunci prosedural dan menggabungkannya dengan menggunakan fitur pada ponsel yaitu SMS sangat diperlukan dan menguntungkan saat ini dan dilengkapi dengan fitur untuk mengatasi pengaksesan pintu rumah secara paksa oleh orang asing. Sistem ini juga dilengkapi fitur untuk memberikan notifikasi melalui ponsel dan bisa mengunci ataupun membuka pintu dari jarak jauh dengan mengirim SMS, sehingga apabila pemilik meninggalkan rumah dan lupa mengunci pintu, hal tersebut dapat diatasi dengan mudah dan efisien. Sistem yang dirancang memiliki 2 input, yaitu kode kombinasi dan pesan singkat (SMS). Mikrokontroler akan menerima informasi, baik dari kombinasi kode maupun pesan singkat (SMS). Kode kombinasi diterapkan melalui konsep Analog to Digital Converter (ADC) melalui perubahan tegangan oleh potensiometer dan hasilnya berupa digit yang ditampilkan di Liquid Crystal Display (LCD). Pesan singkat (SMS) diterapkan melalui pemanfaatan sistem SMS gateway melalui sebuah modul GSM. Hasil yang didapat dari penelitian ini adalah respon time sistem untuk mengirimkan notifikasi kepada pemilik rumah maupun nomor darurat saat pintu diakses melalui kode kombinasi adalah 2,2 - 2,3 detik dan melalui pesan singkat adalah 2,1 - 2,2 detik, serta saat rumah dibuka secara paksa (dibobol) adalah 7,729 detik.
\end{abstract}

Kata Kunci: Home security, Short Message Service, Microcontroller.

\section{Abstract}

Home security is a mandatory requirement of every homeowner in avoiding and minimizing criminal acts in the form of robbery or burglary of the house. One of example of traditional systems that are still widely used are home alarms. But along with the development of today's technology home security systems have an increasingly many types. The home security system is implemented through a combination of procedural locking and combining it using the features of the phone that SMS is indispensable and profitable nowadays. This system has additional features to overcome the forced door access by foreigners. This system is also equipped to provide notification via phone and can lock or open the door remotely by sending SMS, so if the owner leaves the house and forgot to lock the door, it can be solved easily and efficiently. The system designed has 2 inputs, which is combination code and Short Message Service (SMS). The microcontroller will receive information, either from a combination of code or Short Message Service (SMS). Combination code is applied through Analog to Digital Converter (ADC) concept through voltage change by potentiometer and the result is a digit displayed on Liquid Crystal Display (LCD). Short Message Service (SMS) is implemented through the utilization of SMS gateway system through a GSM module. The results obtained from this research is the response time from the system to send notification to the home owner and emergency number when the door is accessed through the combination code is $2,2-$ 2,3 seconds and through short messages is $2,1-2,2$ seconds, and when the house opened by force (burglarized) is 7,729 seconds.

Keywords: Home security, Short Message Service, Microcontroller.

\section{Pendahuluan}

Dalam perkembangan teknologi yang semakin pesat, memungkinkan adanya berbagai usaha untuk memberikan kemudahan dan kenyamanan bagi manusia. Salah satu usaha dalam dalam memberikan kemudahan dan kenyaman tersebut adalah melalui sistem terintegrasi pada rumah (home integration). 
Sistem terintegrasi yang dapat diterapkan pada rumah adalah sistem yang dapat menutup dan membuka pintu rumah dari jarak jauh tanpa melakukan tindakan langsung dengan pintu tersebut.

Disamping kemudahan dan kenyaman tersebut, diperlukan pula adanya tambahan fitur berupa sistem keamanan rumah yang saat ini menjadi kebutuhan primer setiap pemilik rumah. Hal ini didasari oleh tinggginya tingkat kejadian tindak kriminalitas khususnya pembobolan atau pencurian didaerah perumahan atau perkantoran. Untuk mengatasi hal tersebut, banyak pemilik rumah yang menggunakan tenaga satpam atau private guard dalam waktu 24 jam per hari untuk memantau rumah agar terhindar dari pencurian. Dalam hal ini resiko penjaga saat bertugas menjaga rumah sangat besar, seperti tindakan pencurian yang disertai kekerasan ataupun pembunuhan $^{[1]}$

Dengan memanfaatkan kemampuan mikrokontroler sebagai komponen utama untuk mengontrol pintu secara otomatis dan terhubung serta terintegrasi dengan fitur lainnya melalui pembacaan masukan, pemrosesan data, dan pengontrolan keluaran secara bersamaan dan terprogram. Perancangan sistem keamanan ini memanfaatkan fitur Analog to Digital Converter $(A D C)$ dalam mengunci maupun membuka pintu secara langsung oleh pengguna sehingga tingkat keamanannya lebih tinggi. $A D C$ diterapkan melalui beberapa komponen yang berfungsi sebagai input kode analog dan data digital yang dihasilkan dapat diproses oleh mikrokontroler. Dalam penerapannya sistem akan memberikan feedback berupa pesan singkat yang dikirimkan kepada pemilik rumah saat sistem sedang dioperasikan atau diakses.

Fitur lain yang juga diterapkan dalam sistem ini adalah pemilik rumah dapat mengontrol sistem buka tutup pintu dari jarak jauh melalui pesan singkat. Selain itu sistem keamanan ini sudah secara otomatis standby dan siaga selama 24 jam penuh, sehingga apabila terjadi pembobolan atau cara masuk secara paksa tanpa melalui prosedur yang sesuai, maka sensor magnetic switch akan memicu alarm untuk berbunyi dengan sangat keras dan memberikan notifikasi kepada pemilik rumah dan nomor darurat seperti polisi melalui pesan singkat.

\section{Dasar Teori}

\subsection{Sistem Kendali}

Sistem kendali adalah proses pengendalian terhadap satu atau beberapa besaran sehingga berada pada suatu kondisi tertentu yang menjadi target atau acuan. Parameter yang mempengaruhi kerja sistem kendali, yaitu: pengukuran, membandingkan, perhitungan, dan perbaikan. Dalam sistem kendali ada dua jenis yaitu kendali open loop dan kendali close loop. Perbedaan antar kedua kendali tersebut yaitu blok umpan balik (feedback). Sistem kendali open loop tidak memliki blok feedback namun close loop memiliki blok feedback, sehingga dapat mengetahui output sistem. Pada sistem kendali close loop sinyal error dapat diketahui dari perbedaan antara sinyal input dengan sinyal feedback, dimana kontroler akan mengurangi error dan akan memberikan output sistem sesuai yang dinginkan ${ }^{[2]}$.

\subsection{Smart Home System}

Smart Home System merupakan sebuah sistem dalam rumah yang diterapkan secara otomatis yang dapat memberikan segala kemudahan, kenyamanan, dan keamanan. Ilustrasi dari smart home system dapat dilihat pada gambar 1 .

Secara teknis, sistem yang diterapkan dalam smart home dikendalikan dan diprogram secara terstruktur melalui perangkat atau sebuah kontroler, seperti komputer, mikrokontroler, maupun perangkat lainnya. Smart home system dapat mengendalikan hampir semua perlengkapan dan peralatan yang berada di rumah, mulai dari pengaturan tata lampu, pengatur suhu ruangan secara otomatis, hingga ke berbagai peralatan rumah tangga yang perintahnya dapat dilakukan melalui suara, sinar infra merah, atau melalui kendali jarak jauh (remote) $)^{[3]}$.

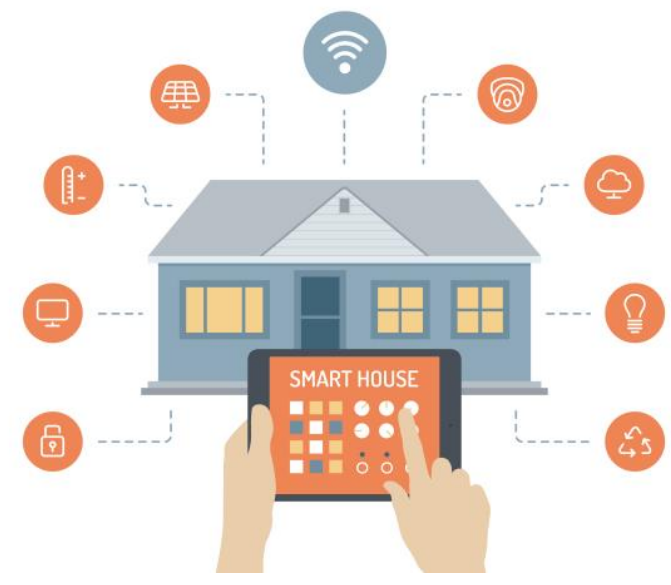

Gambar 1. Smart Home System

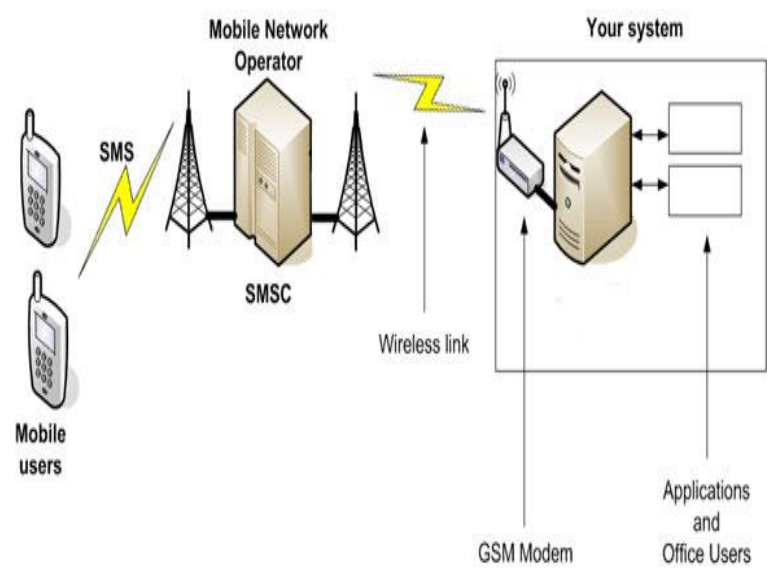

Gambar 2. SMS Gateway System 


\subsection{Mikrokontroler}

Mikrokontroler (pengendali mikro) pada suatu rangkaian elektronik berfungsi sebagai pengendali yang mengatur jalannya proses kerja dari rangkaian elektronik. Di dalam sebuah IC mikrokontroler terdapat $C P U$, memori, timer, saluran komunikasi serial dan paralel, port input/output, $A D C$, dan peralatan internal lainnya yang saling terhubung dan terorganisir (teralamati) dengan baik. Mikrokontroler digunakan dalam sistem elektronik modern, seperti: sistem manajemen mesin mobil, keyboard komputer, instrumen pengukuran elektronik (seperti multimeter digital, synthesizer frekuensi, dan osiloskop), televisi, radio, telepon digital, mobil phone, mivrowave oven, IP Phone, scanner, PLC (Programmable Logic Controller), robot, sistem otomasi, dan lain-lain ${ }^{[4]}$.

\subsection{SMS Gateway}

Istilah gateway dapat diartikan sebagai pintu gerbang. Namun pada dunia komputer, gateway dapat diartikan sebagai jembatan penghubung antara satu sistem dengan sistem yang lain, sehingga dapat terjadi pertukaran data antar sistem tersebut. Dengan demikian, SMS gateway dapat diartikan sebagai pintu gerbang atau jalur bagi penyebaran informasi dengan menggunakan SMS. Dengan media ini, kita dapat menyebarkan pesan kebanyak nomor sekaligus secara otomatis dan cepat. Dengan menggunakan program tambahan yang dapat dibuat sendiri, pengguna dapat lebih fleksibel dalam mengirim/menerima SMS sesuai dengan aturan yang ditetapkan $^{[5]}$. Alur kerja sistem SMS gateway ditunjukkan pada gambar 2 .

\section{Perancangan Sistem}

Desain sistem atau perancangan sistem adalah merancang atau mendesain suatu sistem yang baik, yang isinya adalah langkah-langkah operasi dalam proses pengolahan data dan prosedur untuk mendukung operasi sistem. Desain ini digunakan sebagai acuan gambaran umum sistem atau mendefiniskan cara kerja sistem secara singkat dan umum.

\subsection{Perancangan Perangkat Keras Sistem}

Dalam sistem ini, komponen utama yang digunakan adalah mikrokontroler yang berperan sebagai otak dari sistem yang menghubungkan antara masukan dan keluaran sistem seperti yang terlihat pada gambar 3. Platform mikrokontroler yang digunakan dalam sistem ini adalah Arduino Uno. Power Supply digunakan untuk menyuplai tegangan ke mikrokontroler. Solenoid lock door yang digunakan adalah solenoid $12 \mathrm{~V}$ dan untuk mengontrolnya melalui Arduino Uno diperlukan tambahan driver transistor yang berfungsi sebagai switch $5 \mathrm{~V}$ ke $12 \mathrm{~V}$ saat dibutuhkan. Untuk penerimaan data berupa SMS digunakan modul GSM dengan tipe SIM8001. Untuk menurunkan tegangan dari 5V ke 3,7V sebagai catuan SIM8001 maka digunakan buck converter. Sensor magnetic switch yang digunakan adalah tipe Normally Close. $L C D$ yang digunakan adalah $L C D$ dot matriks tipe $2 \times 16$.

\subsection{Perancangan Perangkat Lunak Sistem}

Perancangan perangkat lunak sistem keamanan rumah melalui kombinasi kunci pintu dan pesan singkat ditulis menggunakan bahasa pemrograman Arduino, yaitu bahasa C yang meliputi deklarasi setiap library, input dan output sistem, pengaturan baudrate serta pemrograman algoritma setiap jenis input sistem, baik melalui kode kombinasi maupun SMS. Perancangan perangkat lunak sistem dibagi menjadi 2 bagian, yaitu :

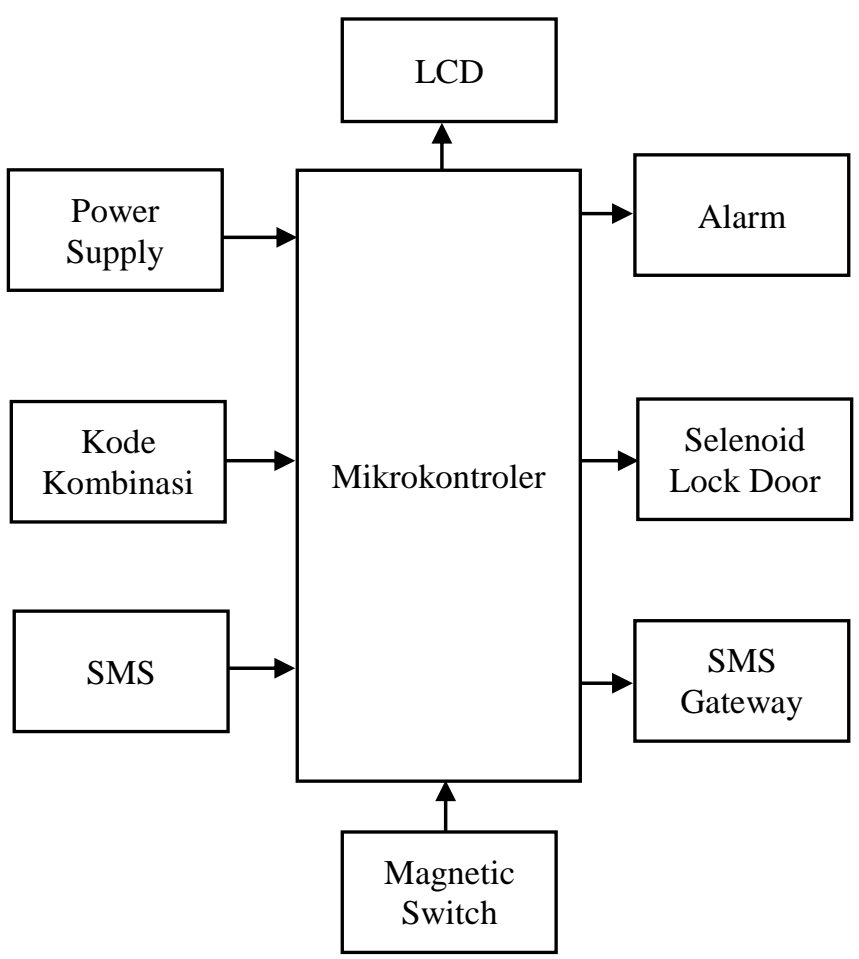

Gambar 3. Desain Perangkat Keras Sistem

Tabel 1. Perolehan Data Dari Pengujian Sistem Melalui Kode Kombinasi Dengan Kode Yang Benar

\begin{tabular}{|c|c|}
\hline Percobaan & $\begin{array}{c}\text { Waktu Yang Diperlukan Sistem } \\
\text { (Respon Time) } \\
\text { Dalam Satuan Detik (s) }\end{array}$ \\
\hline $\mathbf{1}$ & 2,274 \\
\hline $\mathbf{2}$ & 2,274 \\
\hline $\mathbf{3}$ & 2,274 \\
\hline
\end{tabular}




\section{Pengujian dan Analisis}

\subsection{Pengujian Sistem Melalui Kode Kombinasi Dengan Kode Yang Benar}

Dari data diatas dapat diketahui bahwa saat kode yang dimasukkan benar, waktu yang diperlukan sistem untuk mengecek kode dan mengeluarkan output (membuka pintu dan mengirim SMS ke pemilik rumah) adalah 2,274 detik.

- Perancangan Perangkat Lunak Sistem Melalui Kode Kombinasi

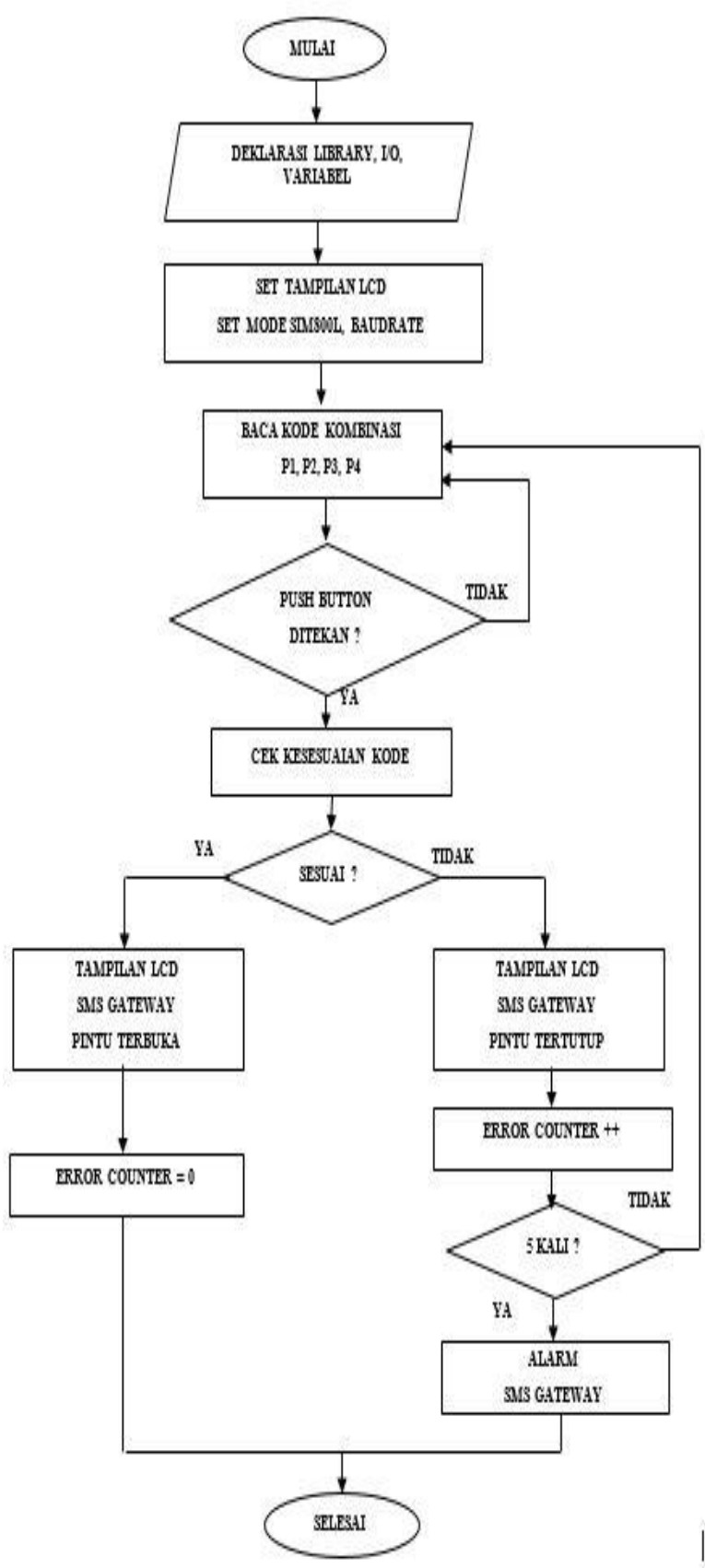

Gambar 4. Diagram Alir Sistem Melalui Kode Kombinasi
- Perancangan Perangkat Lunak Sistem Melalui SMS.

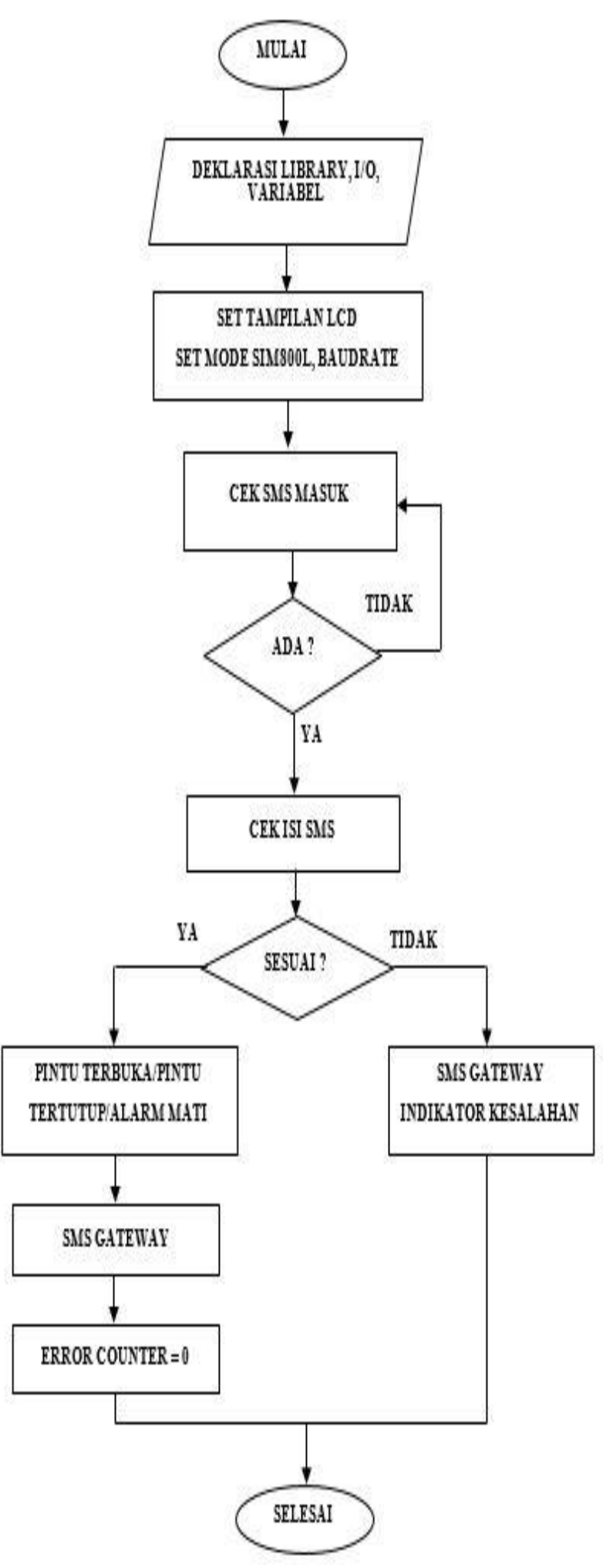

Gambar 5. Diagram Alir Sistem Melalui SMS 


\subsection{Pengujian Sistem Melalui Kode Kombinasi Dengan Kode Yang Salah}

Berdasarkan keempat data yang telah didapat melalui tabel di atas, baik dengan menggunakan kode yang salah di digit petama, kedua, ketiga, maupun keempat dapat dilihat bahwa waktu yang diperlukan sistem untuk mengirim SMS kepada pemilik rumah dan mengaktifkan indikator kesalahan tidak berbeda dari masing-masing pengujian, yaitu 2,320 detik.

Melalui respon time yang terlihat pada kurva di atas, pengecekan kode yang dilakukan oleh sistem adalah secara keseluruhan setelah push button ditekan. Artinya kode yang dibaca akan ditampung dalam satu blok terlebih dahulu, dan setelah push button ditekan maka kode yang ada di dalam blok tersebut akan diproses oleh mikrokontroler secara keseluruhan. Hal ini sesuai dengan struktur program yang telah dirancang.

\subsection{Pengujian Sistem Melalui Pesan Singkat Dengan Format Yang Benar}

Berdasarkan tabel diatas, dapat dilihat bahwa saat format teks yang dikirim berjumlah 11 karakter, yaitu "openthedoor" sistem membutuhkan waktu 2,258 detik. Saat format teks yang dikirim berjumlah 7 karakter, yaitu "alarmoff" sistem membutuhkan waktu 2,114 detik. Saat format teks yang dikirim berjumlah 12 karakter, yaitu "closethedoor" sistem membutuhkan waktu rata-rata 2,112 detik.

Maka dari itu, dapat disimpulkan bahwa jumlah karakter tidak terlalu berpengaruh pada waktu yang dibutuhkan sistem untuk mengecek kesesuaian format. Perbedaan waktu yang ada pada tabel dipengaruhi oleh susunan program yang ada pada mikrokontroler.

\subsection{Pengujian Sistem Melalui Pesan Singkat Dengan Format Yang Salah}

Berdasarkan ketiga data yang telah didapat melalui tabel di atas, baik dengan format yang benar di 6 karakter pertama, atau format yang benar di 6 karakter terakhir, maupun format acak (salah keseluruhan), waktu yang diperlukan sistem untuk mengirim SMS kepada pemilik rumah dan mengaktifkan indikator kesalahan tidak berbeda dari masing-masing pengujian, yaitu 2,259 detik.

\subsection{Pengujian Sistem Melalui Sensor Magnetic Switch}

Pengujian dilakukan untuk mengetahui kinerja magnetic swtich melalui seberapa cepat sistem merespon saat terjadi pembukaan pintu secara paksa (pembobolan/tanpa prosedur). diperlukan sistem berupa indikator kesalahan yaitu alarm dan SMS feedback kepada pemilik rumah dan nomor darurat adalah 7,729 detik.

Tabel 2. Perolehan Data Dari Pengujian Sistem Melalui Kode Kombinasi Dengan Kode Yang Salah

\begin{tabular}{|c|c|c|}
\hline NO & $\begin{array}{c}\text { Posisi } \\
\text { Kesalahan } \\
\text { digit }\end{array}$ & $\begin{array}{c}\text { Waktu Yang Diperlukan } \\
\text { Sistem (Respon Time) } \\
\text { Dalam Satuan Detik (S) }\end{array}$ \\
\hline $\mathbf{1}$ & Posisi I & $\mathbf{2 , 3 2 0}$ \\
\hline $\mathbf{2}$ & Posisi II & $\mathbf{2 , 3 2 0}$ \\
\hline $\mathbf{3}$ & Posisi III & $\mathbf{2 , 3 2 0}$ \\
\hline $\mathbf{4}$ & Posisi IV & $\mathbf{2 , 3 2 0}$ \\
\hline
\end{tabular}

Tabel 3. Perolehan Data Dari Pengujian Sistem Melalui Format SMS Yang Benar

\begin{tabular}{|c|c|c|c|}
\hline No & $\begin{array}{c}\text { Karakter } \\
\text { Yang } \\
\text { Dikirim }\end{array}$ & $\begin{array}{c}\text { Waktu Yang } \\
\text { Diperlukan Sistem } \\
\text { (Respon Time) } \\
\text { Dalam Satuan Detik } \\
(\mathrm{s})\end{array}$ & Output \\
\hline 1 & $\begin{array}{c}\text { openthed } \\
\text { oor }\end{array}$ & 2,258 & $\begin{array}{c}\text { Pintu } \\
\text { Terbuka }\end{array}$ \\
\hline 2 & alarmoff & 2,114 & Alarm \\
\hline 3 & $\begin{array}{c}\text { Closethed } \\
\text { oor }\end{array}$ & 2,112 & $\begin{array}{c}\text { Pintu } \\
\text { Tertutup }\end{array}$ \\
\hline
\end{tabular}

Tabel 4. Perolehan Data Dari Pengujian Sistem Melalui Format SMS Yang Salah

\begin{tabular}{|l|l|l|}
\hline No & Karakter Yang Dikirim & Output \\
\hline 1 & Openthishsd & 2,259 \\
\hline 2 & kdkdeijeniniefhedoor & 2,259 \\
\hline 3 & dwuwdw2 & 2,259 \\
\hline
\end{tabular}

Tabel 5. Perolehan Data Dari Pengujian Sistem Saat Pintu Dibuka Paksa

\begin{tabular}{|c|c|}
\hline Percobaan & $\begin{array}{c}\text { Waktu Yang Diperlukan } \\
\text { Sistem (Respon Item) Dalam } \\
\text { satuan Detik (s) }\end{array}$ \\
\hline 1 & 7,729 \\
\hline 2 & 7,729 \\
\hline 3 & 7,729 \\
\hline
\end{tabular}

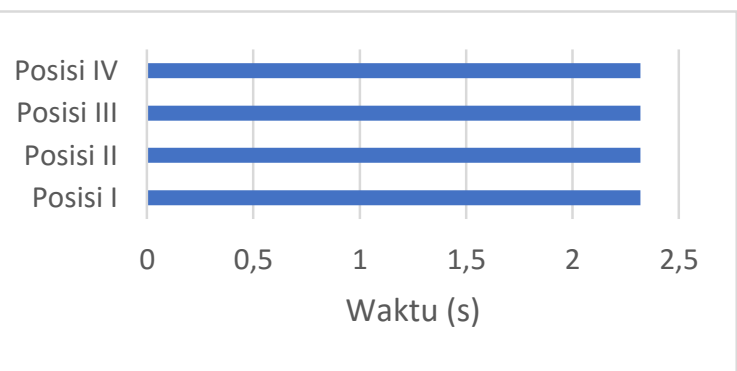
Gambar 6. Kurva Perbandingan Waktu Respon Time Sistem terhadap Kesalahan Kode Berdasarkan Letak Digit




\section{Kesimpulan}

Berdasarkan hasil pengujian dan analisis sistem keamanan rumah melalui kombinasi kunci pintu dan pesan singkat berbasis mikrokontroler ini didapat beberapa kesimpulan, yaitu respon time yang dibutuhkan sistem untuk mengirimkan notifikasi kepada pemilik rumah maupun nomor darurat saat pintu diakses melalui kode kombinasi adalah 2,2 2,3 detik. Oleh karena itu, sistem yang dirancang sudah sesuai dengan yang diinginkan. Respon time yang dibutuhkan sistem untuk mengirimkan notifikasi kepada pemilik rumah maupun nomor darurat saat pintu diakses melalui pesan singkat adalah 2,1 - 2,2 detik. Oleh karena itu, sistem yang dirancang sudah sesuai dengan yang diinginkan. Respon time yang dibutuhkan sistem untuk merespon dan mengirimkan notifikasi kepada pemilik rumah maupun nomor darurat saat rumah dibuka secara paksa (dibobol) adalah 7,729 detik. Oleh karena itu, sistem keamanan rumah yang dirancang cukup responsif terhadap pengaksesan pintu rumah yang tidak sesuai dengan prosedur.

\section{Daftar Pustaka:}

[1] T. Wahyudi, "Sistem Keamanan Rumah Berbasis Teknologi Open Source Dengan Menggunakan Motion dan SMS Gateway,' UPN Veteran, Jawa Timur, 2011.

[2] Ogata, Katsuhiko. "Modern Control Engineering". Prentice Hall, 2002.

[3] Y. D. Shandy V.D, A. Rakhmatsyah dan N. A. Suwastika, "Implementasi Sistem Kunci Pintu Otomatis Untuk Smart Home Menggunakan SMS Gateway," Telkom University, Bandung, 2015.

[4] A. Winoto, Mikrokontroler AVR ATmega8/16/32/8535 : Konsep Mikrokontroler, Bandung: Informatika, 2008.

[5] Tyas, "SMS Gateway". Available : http://informatika.web.id/category/SMSgateway. [Diakses 15 Desember 2012, 08:14 WIB]. 